\title{
Dear old peonies-for gene banks and gardeners; microsatellite fingerprinting of herbaceous peonies in Fennoscandia
}

\author{
Pirjo Tanhuanpää (D) Sirkka Juhanoja • Linnea Oskarsson • Mari Marstein • \\ Merja Hartikainen
}

Received: 9 September 2020/ Accepted: 29 April 2021/Published online: 18 May 2021

(C) The Author(s) 2021

\begin{abstract}
The genetic diversity of 334 herbaceous peonies from Fennoscandia was analysed using 18 microsatellites (simple sequence repeats, SSRs). The samples included peonies mostly from Finnish home gardens (284) and nurseries (5) as well as from Norwegian (20) and Swedish (25) peony collections. The study focused on the following species and hybrids: Paeonia anomala L., $P . \times$ hybrida Pall., $P$. officinalis 'Nordic Paradox' (Marstein 2015), $P$. tenuifolia L., and P. $\times$ festiva Tausch. The 18 microsatellites amplified a total of 249 alleles and were used to calculate genetic distances between samples and to build a dendrogram. In the dendrogram, samples formed clear groups according to their species. The outcome from the genetic analysis was mainly confirmed by preliminary morphological
\end{abstract}

Supplementary Information The online version contains supplementary material available at https://doi.org/10.1007/ s10722-021-01201-9.

P. Tanhuanpää $(\bowtie) \cdot$ M. Hartikainen

Production Systems, Natural Resources Institute Finland

(Luke), 31600 Jokioinen, Finland

e-mail: pirjo.tanhuanpaa@luke.fi

M. Hartikainen

e-mail: merja.hartikainen@luke.fi

S. Juhanoja

Production Systems, Natural Resources Institute Finland

(Luke), 31600 Jokioinen, Finland

e-mail: ext.sirkka.juhanoja@luke.fi observations of the Finnish home garden samples performed within the project and the previous morphological study of peonies in Norwegian clone archives. The results of the study will be used to create a Finnish genetic resources collection of the most diverse and vigorous peonies, and to update the Norwegian and Swedish collections.

Keywords Gene bank - Genetic diversity - Genetic resources $\cdot$ Microsatellite $\cdot$ Peony $\cdot$ Simple sequence repeat $(\mathrm{SSR})$

\section{Introduction}

Peonies (only one genus, Paeonia, in the family Paeoniacea) are native to Asia, South Europe and the western parts of North America (Hong 2010). Several

\footnotetext{
L. Oskarsson

The Swedish National Gene Bank for Vegetatively Propagated Horticultural Crops, The Programme for e-mail: linnea.oskarsson@slu.se

M. Marstein .

MiA-Museene I Akershus, Strømsvegen 74,

2010 Strømmen, Norway

e-mail: mmarste@online.no
} Diversity of Cultivated Plants, The Swedish University of Agricultural Sciences, P.O. 57, S-230 53 Alnarp, Sweden 
thousand years ago, they were used as medicinal plants by the Chinese, who believed that their roots possessed medicinal properties (Hsu et al. 1986). They were then used as ornamental plants from the late $1700 \mathrm{~s}$ (Harding 1917), and are currently among the most popular garden plants in temperate regions. They come in two types: tree peonies, which are shrubs with deciduous leaves, and herbaceous peonies. Both types are mainly multiplied by vegetative propagation, but some species can be propagated by seed.

The current consensus of the number of known species in the genus Paeonia is 33 (Christenhusz and Byng 2016), and they can be divided into three sections: sect. Moutan, sect. Paeonia, and sect. Onaepia (Stern 1946). Sect. Moutan contains 9 woody species (e.g. P. suffruticosa Andrews) endemic to China; sect. Paeonia includes 25 herbaceous species with the widest distribution, mainly in the Mediterranean and Eastern Asiatic regions; and sect. Onaepia two herbaceous species, in western North America and Mexico (Ji et al. 2012).

The biggest section of peonies, Paeonia, contains long-lived perennial herbaceous species whose leaves and stems die during winter but whose roots and crowns stay underground to resume growth in spring. Herbaceous peonies are important traditional flowers in China but are also highly valued as ornamentals in Europe and USA. They are very diverse in morphology and ploidy level (Hao et al. 2016). The basic chromosome number is five (Dark 1936). Hybridisation is important in nature and in the development of new cultivars leading to triploid and tetraploid chromosome numbers.

In the Nordic countries, peonies have long been important as medicinal and ornamental plants. In Sweden, peonies (P. x festiva Tausch and P. officinalis L.) are mentioned in medical manuscripts from the sixteenth century (Larsson 2009). Little is known about the introduction of peonies in Sweden, but in the 1680s, P. officinalis, P. x festiva, P. peregrina Mill., and $P$. mascula (L.) Mill. were included in the lists of plants grown in the botanical garden in Uppsala (Martinsson \& Ryman 2007). In the late nineteenth century, $P . \times$ festiva 'Rubra Plena' was said to be one of the most common perennials in Swedish gardens (O.T. 1890). In Norway, peonies were first mentioned in a Norwegian gardening book, Christian Gartner's Horticultura from 1694: «Paon of all colours» (Balvoll and Weisaeth 1994). All the peonies covered in this study grew in the botanic garden in Oslo in 1823. There is even one called hybrida, but we do not know if it is the $P . \times$ hybrida Pall. we can find in Nordic gardens today (Rathke 1823). In Finland, according to an old written document, peonies have been grown from the end of the seventeenth century, as a medicine for epilepsy (Ruoff 2002). In the nineteenth century, peonies were grown in Finland as ornamentals and there were seeds from a few different peony species on the market. Peonies were also ordered from a nursery in St. Petersburg. Even though peonies have long been cultivated in Finland, there is no collection of peony genetic resources as in Norway and Sweden.

For genetic resources collections, it is very important to be able to distinguish species and cultivars. In addition to tens of peony species, there are a vast number of different cultivars, 7995 in 2007 (Jakubowski et al. 2007). Identification of different peony cultivars requires experience in recognising morphological traits of the plant and the flower, and it takes from two to 10 years before the plant blooms. In addition, flower colour may vary depending on growing site (Zhao et al. 2012). DNA markers can be used in order to simplify cultivar identification and to carry it out at an early stage of the plant. Simple sequence repeat markers (SSRs, microsatellites) were developed for tree peonies (Gai et al. 2012; Gao et al 2013; Guo et al. 2017; Homolka et al. 2010; Hou et al. 2011a, b; Wang et al. 2009; Wu et al. 2014; Yu et al. 2013; Zhang et al. 2011, 2012) and to a lesser extent for P. lactiflora Pall. (Cheng et al. 2011; Gilmore et al. 2013; Ji et al. 2014; Li et al. 2011; Sun et al. 2011; Wan et al. 2020). In addition to identifying cultivars and species, DNA markers can be used to identify hybrid origin, to study genetic diversity and relationships, and for linkage mapping.

Finland, Sweden and Norway have always been strongly connected, both climatically and culturally, and there has been an active contact across borders. In all three countries, it is traditional to pass plants along to friends and relatives, and to take plants with you when you move from your house. Therefore, it was justified to carry out a joint study combining plants from these three countries. In the study, the main emphasis was on the following species: P. anomala L., P. $\times$ hybrida, $P$. officinalis 'Nordic Paradox' (Marstein 2015), $P$. tenuifolia L., and $P . \times$ festiva. The aim was to collect leaf samples and roots from old peonies 
from Finnish home gardens and nurseries (roots for planting, for subsequent morphological and phenological observations) and to study their genetic diversity using SSR markers. The same set of markers was also used to study genetic diversity of herbaceous peonies from Norwegian and Swedish peony collections. The final goal is to create a Finnish collection of the most diverse and vigorous peonies with a good ornamental value. In addition, results of the study will be used to update Norwegian and Swedish collections, to exclude duplicates and to confirm some identities.

\section{Materials and methods}

\section{Plant material}

Plant material contained peony samples from Finland, Norway and Sweden (Figs. 1, 2). In Finland, we first sought to obtain information about the most rare peony species grown in private Finnish gardens and nurseries (Ruoff 2002; Peltola and Koivu 2007). The following species were selected for the study: $P$. anomala L., $P . \times$ hybrida, P. officinalis 'Nordic Paradox' (Juhannuspioni in Finnish), P. tenuifolia, and $P . \times$ festiva, based on their assessed risk of extinction. Every change in the ownership of a garden will put them at risk, because new owners seldom have an emotional connection to the plants in an old garden, and they often want to simplify and modernise. These species have been cultivated in Fennoscandia for a long time. They are typical pass-along plants and not in commercial production. To obtain peony samples from Finnish home gardens, a call for plants was announced in 2018-2019. We wanted to collect oral history, photos and locations of the selected peony species cultivated in Finland in the 1950s or earlier. Owners of old peony varieties and landraces were asked to describe their plants using an online registration form (www.luke.fi/ilmoitakasvi). This form is still available and continues to be accessed by owners. Altogether, 690 peony announcements were obtained, and the samples were given a number with a prefix 'LUKE' (referring to the Natural Resources Institute Finland, Luonnonvarakeskus in Finnish, abbreviation "Luke"). A total of 335 plants from the announcements were chosen for the study. Peonies apparently (based on description and/or photos) not representing the target species were not chosen. Otherwise, selection criteria included interesting cultivation history and, in particular, the age of the plant (more than 60 years old). Leaf samples of the peonies were requested for DNA analysis, as well as roots for planting, for later morphological and phenological observations. Finally, we received leaves from 284 plants (Fig. 1) but the owners did not send roots from all of them. Roots were planted in pots and kept outdoors during autumn, and stored indoors at a temperature below $+5{ }^{\circ} \mathrm{C}$ during winter. In early spring they were transferred to a greenhouse and finally planted in a field at Luke's experimental station in Piikkiö $\left(60^{\circ} 25^{\prime} 30^{\prime \prime} \mathrm{N}, 022^{\circ} 31^{\prime} 00^{\prime \prime} \mathrm{E}\right)$ in June 2019. Preliminary morphological observations were made from 243 plants in the greenhouse, which were classified, when possible, as different species according to leaf shape, leaf hairiness, leaf colour, flower shape, and flower colour. In addition to peonies from home gardens, five reference samples were included: one $P . x$ festiva 'Rosea Plena' (sample number: FIN-2019-75) and one 'Alba Plena' (FIN-2019-74) from a Finnish nursery, and three $P$. lactiflora samples (LUKE-5324, LUKE-5325, LUKE-5326) from Luke's exhibition garden Wendla. P. lactiflora samples were included in order to act as references for this peony group and to test the functionality of SSRs, which were mainly derived from this species.

Norwegian samples for the peony collection were collected through a project financed by the Norwegian Gene Resources Centre between 2003 and 2008. Botanists and other professionals visited garden owners in different parts of Norway, interviewing them and collecting plants, with a preference for gardens containing a selection of traditional plants. The collected plants were planted in separate departments of the botanical gardens in Kristiansand, Oslo, Trondheim, and Troms $\varnothing$, and at some local museums. Information about the plant's local growing history was documented. From the Norwegian collection, 20 samples were selected for the study and leaf samples were sent to Luke. (Table 1, Fig. 1).

Swedish leaf samples were collected from peonies preserved in the Swedish National Gene Bank for Vegetatively Propagated Horticultural Crops. The gene bank is located at the Swedish University of Agricultural Sciences and contains 2200 older cultivars of fruits, berries, ornamentals, and vegetables. The gene bank was inaugurated in 2016, and the cultivars preserved were collected through nationwide 


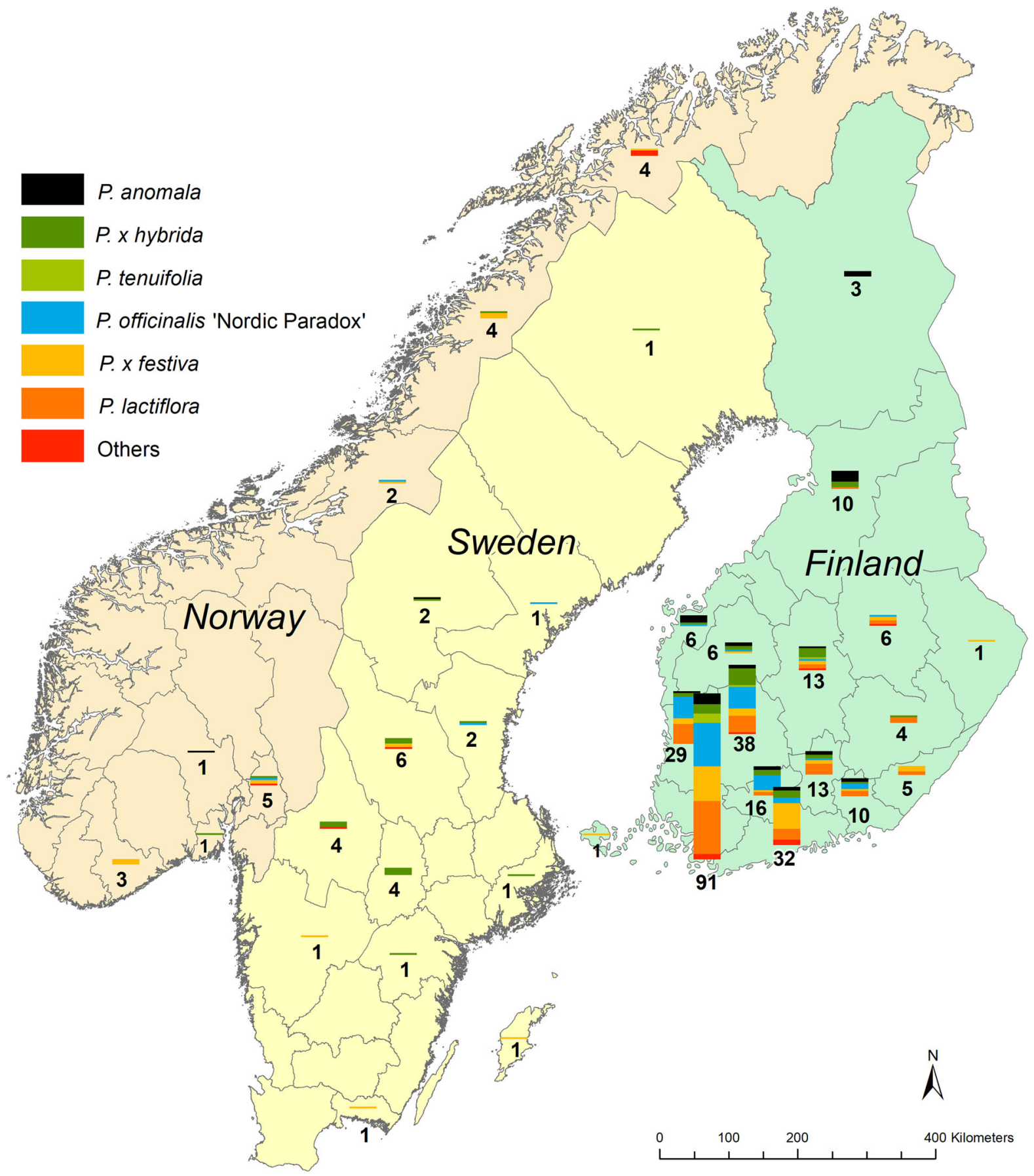

Fig. 1 Geographical map of the peony samples in the study according to their location to provinces. The class 'others' contains peonies from the following groups: P. officinalis and P. officinalis 'Mollis

inventories of garden plants grown in Sweden before 1940 or 1950, depending on plant species. The majority of the cultivars preserved in the gene bank were collected from private gardens throughout
Sweden, and in addition to documenting the plants, the histories and traditions associated with them were also documented. The inventories were initiated and implemented by the Programme for Diversity of 

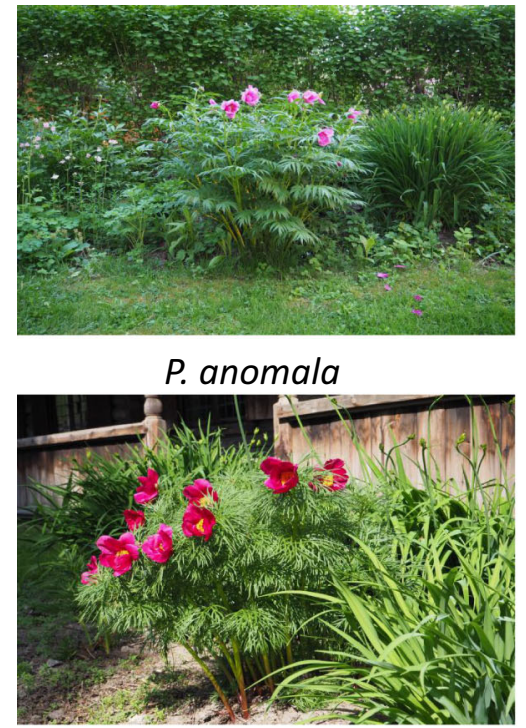

P. x hybrida

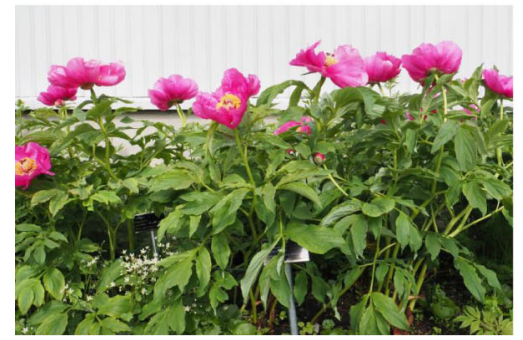

P. officinalis 'Mollis'
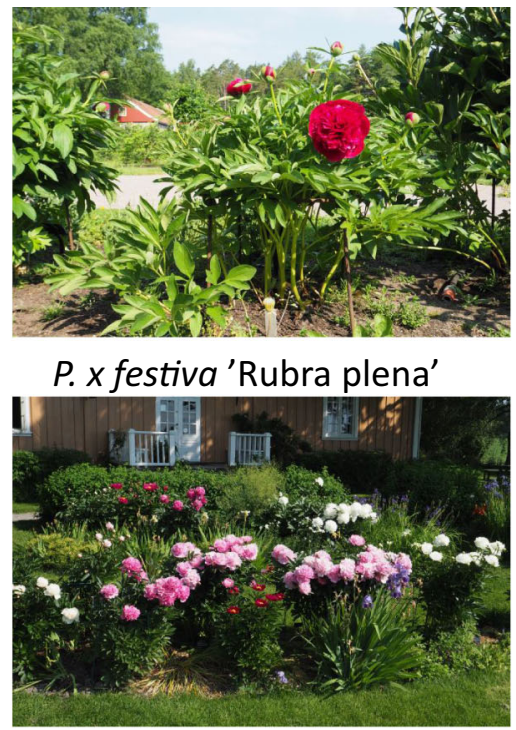

P. lactiflora

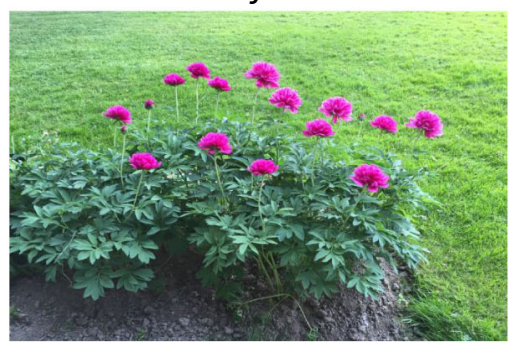

P. officinalis 'Nordic Paradox'

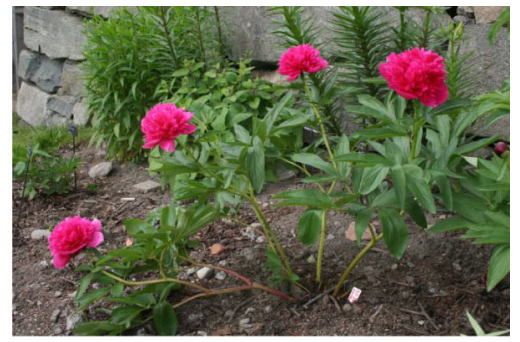

P. x festiva 'Rosea plena'

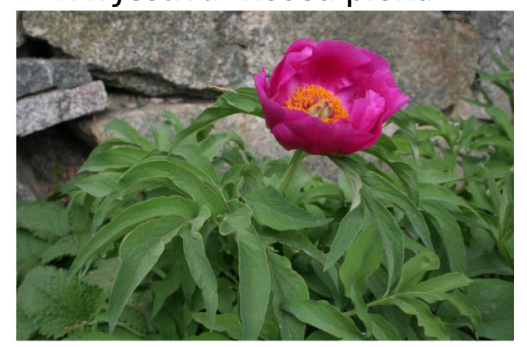

P. officinalis

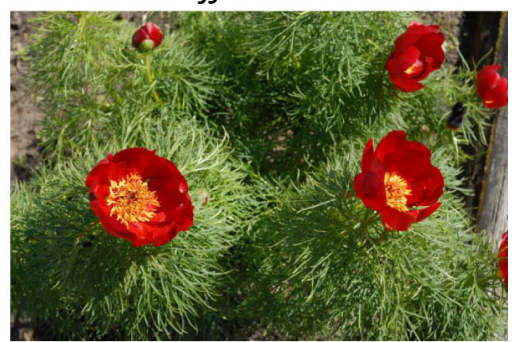

P. tenuifolia

Fig. 2 Photos of different peony species taken by Mari Marstein, except P. tenuifolia by Mikko Uusi-Honko

Cultivated Plants, Sweden's national programme for plant genetic resources. All in all, 75 accessions of peonies are preserved in the Swedish National Gene Bank. Of these, 25 belong to the species selected by Luke for genetic testing, and leaf samples from these accessions were sent to Luke in spring 2018 (Table 1, Fig. 1).

E.Z.N.A ${ }^{\circledR}$ SP Plant DNA kit (Omega Bio-tek, Norcross, GA, USA) was used for DNA extractions from frozen peony leaves. In some leaf samples, DNA quality was low (indicated by low A260/A280 and A260/A230 ratios) and created problems in SSR amplification. Therefore, DNA from these samples was further purified using a general protocol of ethanol precipitation. DNA concentrations were measured using a NanoDrop ${ }^{\mathrm{TM}}$ One/One ${ }^{\mathrm{C}}$ Microvolume UVVis Spectrophotometer (Thermo Fisher Scientific Ltd, Vantaa, Finland).
SSR analyses

For the diversity study we selected 44 SSRs developed for $P$. lactiflora and 12 for $P$. suffruticosa from different studies (Cheng et al. 2011; Gilmore et al. 2013; Ji et al. 2014; Li et al. 2011; Sun et al. 2011; Wu et al. 2014). Amplification of SSRs was first tested in three Paeonia species: P. anomala, P. lactiflora (two different genotypes), and $P . x$ hybrida. Those amplifying well in this first trial were further analysed for their polymorphism in five species (16 individuals): $P$. anomala, P. lactiflora, P. x hybrida (four genotypes), $P$. officinalis (two genotypes), and $P$. $x$ festiva (three genotypes), and in five samples with undefined species from Finnish home gardens. Eighteen SSRs (Table 2), which amplified well and were polymorphic, were selected for final analyses. The SSRs were amplified in three PCR reactions according to results from the Multiplex Manager v1.2 program (http:// 
Table 1 Twenty peony samples from the Norwegian collection (NOR) and 25 from the Swedish collection (SWE)

\begin{tabular}{|c|c|c|c|c|}
\hline Species/hybrid & Cultivar & Municipality & Province & Accession number \\
\hline \multirow[t]{15}{*}{ P. $x$ festiva } & 'Rubra Plena' & 4213 Tvedestrand & Agder & NOR-UiA-2003-0248 \\
\hline & 'Rubra Plena' & 4206 Farsund & Agder & NOR-UiA-2006-0135 \\
\hline & 'Rubra Plena' & $3034 \mathrm{Nes}$ & Viken (Akershus) & NOR-GH-2008-09 \\
\hline & 'Rubra Plena' & 1813 Brönnöy & Nordland & NOR-UiT-2002-56 \\
\hline & 'Rubra Plena' & 1837 Melöy & Nordland & NOR-UiT-2002-298 \\
\hline & 'Rubra Plena' & 1806 Svolvær & Nordland & NOR-UiT-2015-399 \\
\hline & 'Rubra Plena' & Tranemo & Västra Götaland & SWE-2018-1 \\
\hline & cf 'Rubra Plena' & Falun & Dalarna & SWE-2018-2 \\
\hline & 'Rubra Plena' & Floda & Dalarna & SWE-2018-3 \\
\hline & 'Rosea Plena' & 4215 Lillesand & Agder & NOR-UiA-2001-1028 \\
\hline & 'Rosea Plena' & 5053 Inderöy & Tröndelag & NOR-NTNU-2004-501 \\
\hline & 'Rosea Plena' & 3033 Ullensaker & Viken (Akershus) & NOR-GH-2007-17 \\
\hline & 'Rosea Plena' & 5402 Harstad & Troms & NOR-UiT-2010-70 \\
\hline & cf 'Rosea Plena' & Hasslö & Blekinge & SWE-2018-4 \\
\hline & cf 'Mutabilis Plena' & Klintehamn & Gotland & SWE-2018-5 \\
\hline \multirow[t]{8}{*}{ P. officinalis } & 'Nordic Paradox' & $3034 \mathrm{Nes}$ & Viken (Akershus) & NOR-GH-1980-01 \\
\hline & 'Nordic Paradox' & 5037 Levanger & Tröndelag & NOR-NTNU-2005-254 \\
\hline & 'Nordic Paradox' & Trönödal & Gävleborg & SWE-2018-23 \\
\hline & 'Nordic Paradox' & Sidensjö & Västernorrland & SWE-2018-24 \\
\hline & & 3026 Aurskog-Höland & Viken (Akershus) & NOR-GH-2006-23 \\
\hline & 'Mollis' & 5401 Tromsö & Troms & NOR-UiT-2004-207 \\
\hline & 'Mollis' & 5401 Tromsö & Troms & NOR-UiT-2004-181 \\
\hline & 'Mollis' & 5401 Tromsö & Troms & NOR-UiT-2010-153 \\
\hline P. officinalis? & & Filipstad & Värmland & SWE-2018-21 \\
\hline P. officinalis? & & Gustavs & Dalarna & SWE-2018-22 \\
\hline \multirow[t]{18}{*}{ P. $x$ hybrida } & & 3030 Lilleström & Viken (Akershus) & NOR-GH-2009-09 \\
\hline & & 1849 Hamaröy & Nordland & NOR-UiT-2004-120 \\
\hline & & 0729 Færder & Vestfold & NOR-UiT-1993-982 \\
\hline & & Kristinehamn & Värmland & SWE-2018-6 \\
\hline & & Falun & Dalarna & SWE-2018-7 \\
\hline & & Hagfors & Värmland & SWE-2018-8 \\
\hline & & Smedjebacken & Dalarna & SWE-2018-9 \\
\hline & & Kälarne & Jämtland & SWE-2018-10 \\
\hline & & Gagnef & Dalarna & SWE-2018-11 \\
\hline & & Borensberg & Östergötland & SWE-2018-12 \\
\hline & & Täby & Stockholm & SWE-2018-13 \\
\hline & & Odensbacken & Örebro & SWE-2018-14 \\
\hline & & Gyttorp & Örebro & SWE-2018-15 \\
\hline & & Dyltabruk & Örebro & SWE-2018-16 \\
\hline & & Brevens Bruk & Örebro & SWE-2018-17 \\
\hline & & Öjebyn & Norrbotten & SWE-2018-18 \\
\hline & & Delsbo & Gävleborg & SWE-2018-19 \\
\hline & & Grunnebacka & Värmland & SWE-2018-20 \\
\hline \multirow[t]{2}{*}{ P. anomala } & & 3007 Ringerike & Viken (Buskerud) & NOR-GH-2009-10 \\
\hline & & Östersund & Jämtland & SWE-2018-25 \\
\hline
\end{tabular}




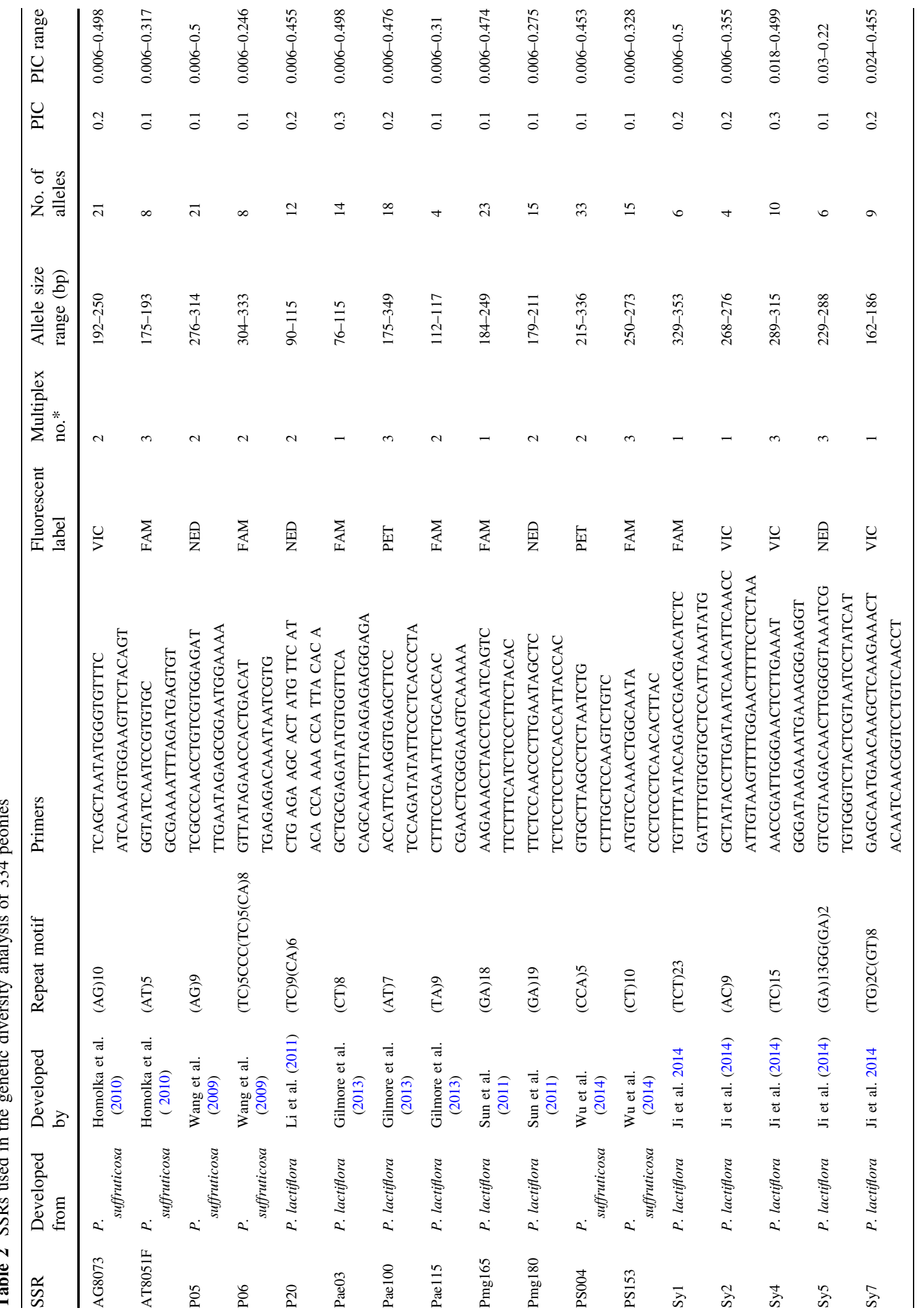


Fig. 3 The dendrogram of 334 peony samples, of which 25 are from Sweden (prefix SWE), 20 from Norway (prefix NOR), and the rest from Finland: 284 from home gardens (prefix LUKE) and 5 references (LUKE-5324, LUKE-5325, and LUKE$5326=$ P. lactiflora, FIN-2019-74 = P. x festiva 'Alba Plena', FIN-2019-75 $=P$. x festiva 'Rosea Plena'). Confidence levels greater or equal to $50 \%$ from bootstrap analysis of 1000 replicates are indicated. Eight or more identical genotypes have been united under a single name (duplicate groups 1-7, number of samples in parenthesis) to facilitate interpretation of the dendrogram. The individual sample names in the duplicate groups are presented in Table S1

multiplexmanager.com). To separate and visualise amplified products, an ABI PRISM ${ }^{\circledR} 310$ Genetic Analyzer (Thermo Fisher Scientific Ltd, Vantaa, Finland) was used. The forward primer of each primer pair was labelled with a fluorescent dye, FAM ${ }^{\mathrm{TM}}$ (5carboxyfluorescein), NED ${ }^{\mathrm{TM}}$, VIC ${ }^{\circledR}$ or PET ${ }^{\circledR}$. The PCR amplification conditions were as follows: 32 cycles of $30 \mathrm{~s}$ at $95^{\circ} \mathrm{C}, 90 \mathrm{~s}$ at $57^{\circ} \mathrm{C}$, and $30 \mathrm{~s}$ at $72^{\circ} \mathrm{C}$ in a BioRad C1000 Thermal Cycler (Bio-Rad, Hercules, California, USA). The program started with an initial denaturation step of $5 \mathrm{~min}$ at $95{ }^{\circ} \mathrm{C}$ and was followed by a final extension step of $30 \mathrm{~min}$ at $60{ }^{\circ} \mathrm{C}$. The PCR amplification was performed in a total volume of $10 \mu$, containing $5 \mu$ l Master Mix from Qiagen Type-it ${ }^{\circledR}$ Microsatellite PCR Kit (Qiagen, Helsinki, Finland), $5 \mathrm{ng}$ of DNA, and 67-400 nM in each primer. PCR products were diluted 1/50 for the ABI runs. GeneMapper® software 5 was used for allele size estimation.

Data analyses

The study contained plants with different and often unknown ploidy levels, and it was impossible to know the dosages of the SSR alleles. In addition, some SSRs might also represent multiple loci (P05 and Pae100, Gilmore et al. 2013). Therefore, each SSR allele was treated as a separate marker locus and a binary code (1/ $0)$ was used for the presence or absence of allele peaks.

Based on the Dice coefficient, a dissimilarity index between samples was counted with DARwin software version 6.0.014 (Dissimilarity Analysis and Representation for Windows, Perrier and JacquemoudCollet 2006) using a bootstrap value of 1000 replications. The dissimilarity matrix was used for building an unweighted neighbour-joining (NJ, Saitou and Nei 


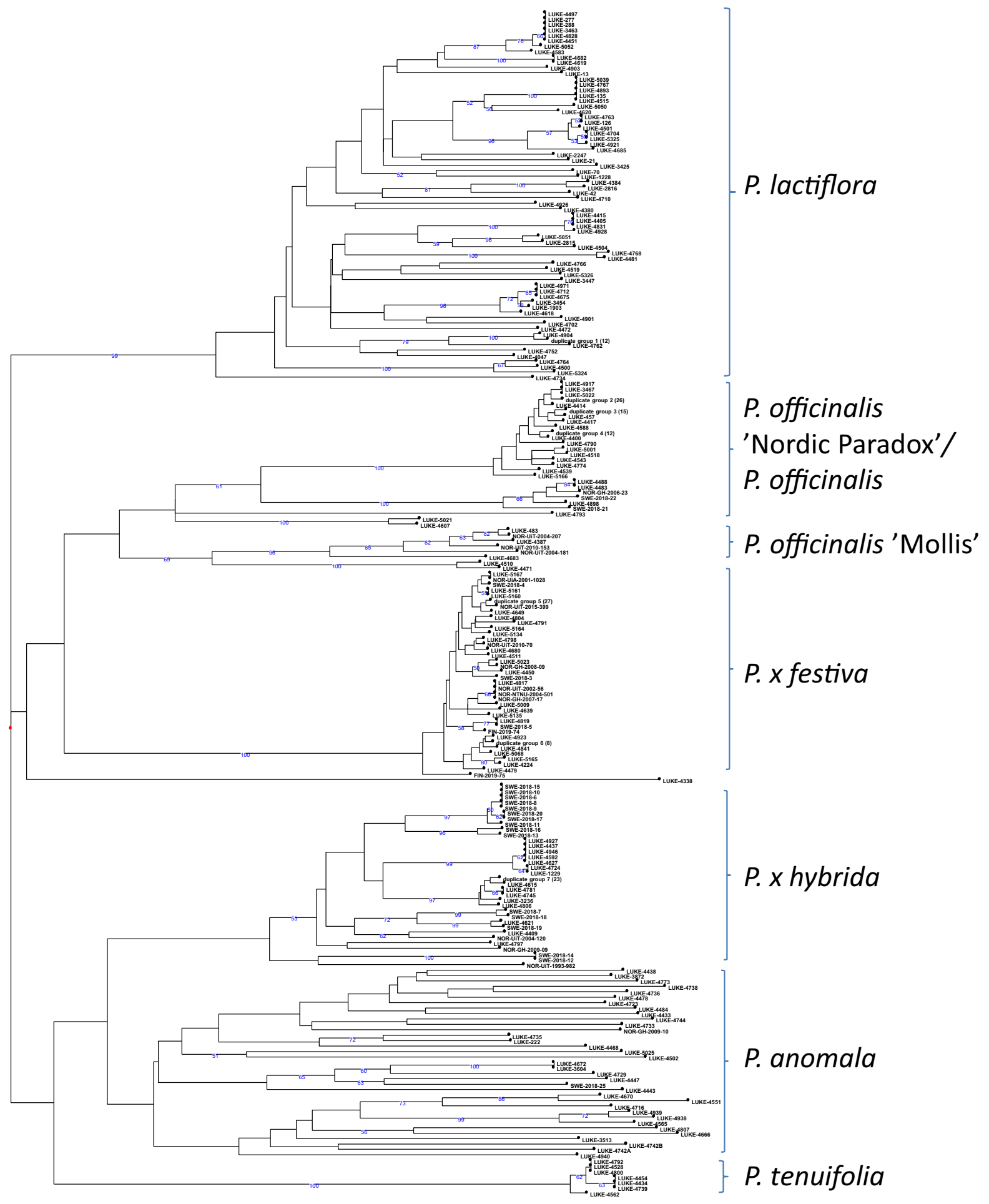


Table 3 The number of samples in each peony group in the NJ tree. One sample (LUKE-4338) did not clearly cluster into any group

\begin{tabular}{|c|c|c|c|c|c|c|c|c|c|}
\hline \multirow[t]{3}{*}{ Group no } & \multirow[t]{3}{*}{ Group name } & \multirow{3}{*}{$\begin{array}{l}\text { Total } \\
\text { no. of } \\
\text { samples }\end{array}$} & \multicolumn{3}{|c|}{ Reference samples from } & \multirow{2}{*}{\multicolumn{4}{|c|}{$\frac{\text { Samples from Finnish home gardens }}{\text { Morphology described }}$}} \\
\hline & & & & & & & & & \\
\hline & & & Finland & Norway & Sweden & Total & $\begin{array}{l}\text { Different } \\
\text { genotypes }\end{array}$ & Total & Inconsistency $^{a}$ \\
\hline 1 & P. lactiflora & 79 & 3 & & & 76 & $49(65 \%)$ & 57 & 0 \\
\hline \multirow[t]{4}{*}{2} & $\begin{array}{l}\text { P. officinalis 'Nordic } \\
\text { Paradox' / P. officinalis }\end{array}$ & 77 & & & & & & & \\
\hline & - P. officinalis 'Nordic Paradox' & 68 & & 2 & 2 & 64 & $16(25 \%)$ & 54 & 0 \\
\hline & - P. officinalis & 6 & & 1 & 2 & 3 & $2(67 \%)$ & 1 & 0 \\
\hline & - separate samples & 3 & & & & 3 & $3(100 \%)$ & 0 & 0 \\
\hline 3 & P. officinalis 'Mollis' & 8 & & 3 & & 5 & $5(100 \%)$ & 5 & 1 \\
\hline 4 & P. $x$ festiva & 71 & 2 & 10 & 5 & 54 & $26(48 \%)$ & 42 & 0 \\
\hline 5 & P. $x$ hybrida & 56 & & 3 & 15 & 38 & $10(26 \%)$ & 35 & 0 \\
\hline 6 & P. anomala & 35 & & 1 & 1 & 33 & $32(97 \%)$ & 28 & 1 \\
\hline 7 & P. tenuifolia & 7 & & & & 7 & $3(43 \%)$ & 4 & 0 \\
\hline Total & & 333 & 5 & 20 & 25 & 283 & 146 & 226 & 2 \\
\hline
\end{tabular}

anconsistency between genetic analysis and morphological evaluation

1987) tree. Polymorphism information content (PIC) of the SSRs was calculated in a free online computer program (Abuzayed et al. 2017) using the formula from Roldan-Ruiz et al. (2000).

\section{Results}

Fifty-six previously reported SSRs were evaluated in order to study genetic diversity in herbaceous peonies. Based on their amplification and polymorphism, the 18 best SSRs (Table 2) were used for final analyses of 334 peony samples. Two of the selected SSRs contained a trinucleotide repeat, and the rest dinucleotide repeats. The PIC values of the SSRs varied from 0.08 (Pmg180) to 0.26 (Sy4) with a mean of 0.16 . Six of the selected SSRs (33\%) were developed from $P$. suffruticosa and 12 (67\%) from P. lactiflora; those from $P$. suffruticosa produced more alleles (mean 18 vs. 12/SSR) but their PIC value was lower (mean 0.13 vs. 0.18 ) than in P. lactiflora SSRs. The 18 SSRs amplified 249 alleles (markers) in total, and the number of alleles per SSR varied from 4 (Pae115) to 33 (PS004).

Genetic distances between samples were visualised with an NJ tree (Fig. 3). The samples formed clear groups, which were named according to previously identified species samples ('references') from Norway, Sweden, and Finland (Table 3): 1) P. x lactiflora, 2) P. officinalis 'Nordic Paradox'/P. officinalis, 3) $P$. officinalis 'Mollis', 4) P. $x$ festiva (based only on morphological observations, no references), 5) $P$. $x$ hybrida, 6) $P$. anomala, and 7) alleged $P$. tenuifolia. In addition, one yellow-flowered peony (LUKE-4338) did not clearly cluster into any group. There were duplicates in all groups, the amount varying from 0 to 75\% among the samples from Finnish home gardens (Table 3, Table S1). All the reference samples fell into their corresponding groups. The two uncertain $P$. officinalis samples (SWE-2018-21 and SWE2018-22, Table 1) from Sweden proved to be $P$. officinalis. Some subgroupings could also be observed within each group, e.g. in $P$. officinalis 'Nordic Paradox'/P. officinalis group, there were clearly separate subgroups for $P$. officinalis 'Nordic Paradox' and for $P$. officinalis; in addition, three separate samples (LUKE-5021, LUKE-4607, and LUKE-4793) did not cluster into either subgroup.

Only ten of the 18 SSRs selected for final analyses were amplified and polymorphic in all species (Table 4). Therefore, even though the total number of polymorphic markers was 249 , the number in each 
Table 4 Amplification of 18 SSRs in different peony species groups. Groups with less than 10 samples have been omitted $(P$. tenuifolia, 7 samples and P.officinalis 'Mollis' group, 8 samples)

\begin{tabular}{|c|c|c|c|c|c|c|}
\hline $\begin{array}{l}\text { Group } \\
\text { no }\end{array}$ & Group name & $\begin{array}{l}\text { No. of polymorphic } \\
\text { SSRs }\end{array}$ & $\begin{array}{l}\text { No. of polymorphic } \\
\text { alleles }\end{array}$ & $\begin{array}{l}\text { No. of private } \\
\text { alleles }\end{array}$ & $\begin{array}{l}\text { SSRs not } \\
\text { amplified }\end{array}$ & $\begin{array}{l}\text { Monomorphic } \\
\text { SSRs }\end{array}$ \\
\hline 1 & P. lactiflora & 17 & 90 & 36 & & Sy1 \\
\hline 2 & $\begin{array}{l}\text { P. officinalis 'Nordic } \\
\text { Paradox' / } \\
\text { P. officinalis }\end{array}$ & 15 & $77(43)^{\mathrm{a}}$ & $20(15)^{b}$ & Pae115, Sy5 & Sy1 \\
\hline 4 & P. $x$ festiva & 14 & 38 & 8 & Sy2, Sy5 & Pae03, Sy1 \\
\hline 5 & P. $x$ hybrida & 15 & 45 & 3 & P06, Sy2 & Sy4 \\
\hline 6 & P. anomala & 17 & 116 & 35 & P06 & \\
\hline
\end{tabular}

${ }^{a}$ Fourty-three if the three separate samples (see text) are not included

${ }^{\mathrm{b}}$ Fifteen if the three separate samples (see text) are not included

group varied greatly, and discrimination between samples within a group was based on 38 ( $P . x$ festiva)-116 ( $P$. anomala) markers. In $P$. anomala and $P$. lactiflora the number of polymorphic SSRs and the number of alleles were the highest among all groups. All species contained private alleles (Table 4), i.e. alleles that were not found in other species, however, they were very seldom (only three markers) amplified from all samples within a species.

A morphological study of peonies in the Norwegian clone archives was conducted in 2018 and 2019 using 12 specific characters. The results are published in a 48-page report on the MiA website-Museums in Akershus (https://dms-cf-05.dimu.org/file/ 03349w5fjobV). Fifteen of the Norwegian samples in the present DNA study were included in the morphological study and there was complete agreement between morphology and DNA markers; all the specimens fell into the expected groups in the dendrogram. Preliminary morphological evaluation from the Finnish home garden samples was carried out in the greenhouse in Piikkiö from 243 samples. The species could not be defined from 17 of the plants due to poor growth or because the plant did not bloom at all. From the remaining 226 samples, only two (LUKE-4940 and LUKE-4387) gave controversial results compared to genetic analysis (Table 3 ). LUKE4940 clustered in the dendrogram to $P$. anomala group but was (clearly) separate from the other samples. The SSRs worked in this sample partly as in $P$. anomala and partly as in P. $x$ hybrida: P05 amplified normally as in $P$. anomala (does not work in $P$. x hybrida) but on the other hand, Sy2 did not amplify and Sy4 was monomorphic as in P. hybrida (Table 4). Morphologically LUKE-4940 seemed to be $P$. $x$ hybrida, however, also containing characters from $P$. anomala. In fact, LUKE-4940 can be P. intermedia C.A. Mey., which has long been thought to be a subspecies of $P$. anomala, even though Hong (2010) thinks that it is a species of its own. LUKE-4387 clustered genetically into the $P$. officinalis 'Mollis' group but morphologically into $P$. officinalis 'Nordic Paradox', however, this plant did not bloom in the greenhouse. According to the photo sent by the owner, LUKE-4387 seems to be 'Mollis', so the genetic result is correct. The morphological identification of samples in the 'Mollis' group was not straightforward but the five samples from home gardens were classified as undefined. Only one of these plants flowered in the greenhouse, and it seemed to be 'Mollis'. The final identification of most of the samples according to morphological and phenological observations from two years of field trials will be reported later in another article. However, some of the samples did not survive the first winter, which diminishes the number of morphological results.

\section{Discussion}

Genetic diversity in peony samples from Swedish and Norwegian peony collections, and from Finnish home gardens and nurseries was assessed with 18 SSRs. The objective of the call for old peonies from Finnish home 
gardens was to obtain the following species: $P$. anomala, $P . \times$ hybrida, $P$. officinalis 'Nordic Paradox', $P$. tenuifolia, and $P . \times$ festiva. In addition to these, samples representing $P$. lactiflora and $P$. officinalis were also obtained. In the dendrogram, different species were clearly separated into their own groups and the identity of a group could be ascertained using Finnish reference samples and previously identified samples from Norwegian and Swedish collections. The separation into different species groups was facilitated due to some SSRs being group-specific, e.g. they did not amplify at all or were monomorphic in certain groups. But on the other hand, due to a lower number of polymorphic markers in some groups, it was perhaps not possible to differentiate between samples, which led to a high number of duplicates (about half of the samples from Finnish home gardens were duplicates). This might of course also represent a real situation: well-growing peonies have spread out across Finland for decades because people have given peony roots to each other. On the other hand, in the $P$. anomala group, nearly all samples from home gardens and nurseries were of a different genotype, and only two samples were genetically identical. This can be explained by the highest number of polymorphic markers in the $P$. anomala group and the fact that this species is mainly propagated by seeds.

The informativeness level of markers can be assessed using PIC values, which reflect the diversity and distribution of alleles. In the present study, the PIC values were mostly in the category of low $(<0.25$, Botstein et al. 1980), the mean being 0.16. One reason for this is that the SSRs were developed in a different species than the ones in which they were used, and therefore, did not amplify or were monomorphic in some species groups. In addition, SSRs had to be scored as dominant markers due to unknown ploidy levels, and this also diminishes PIC values. In a comparable study of rhubarb, PIC values were similar, varying from 0.05 to 0.16 with a mean of 0.12 (Tanhuanpää et al. 2019).

There has been controversy over the species' identity within the $P$. anomala complex, which contains herbaceous peonies in Central Asia, Siberia, and adjacent North Eastern European regions (Hong and Pan 2004). P. x hybrida of Pallas in this complex was, according to A. P. de Candolle (1818), a garden hybrid between P.anomala and P.tenuifolia, also occurring in the wild (Stern 1946). On the other hand,
Anderson (1818) regarded $P . x$ hybrida as synonymous with $P$. tenuifolia for the first time and, after taxonomic revision, Hong and Pan (2004) were of the same opinion. In our study, $P$. $x$ hybrida, $P$. anomala, and $P$. tenuifolia belonged to a bigger cluster, within which they each formed their own subgroups, suggesting that $P$. $x$ hybrida and $P$. tenuifolia are different species. However, because there were only $7 P$. tenuifolia samples, and they only represented three different genotypes, more samples are needed to verify this observation.

The cultivar name of some reference samples was known (Table 1). Samples under the same cultivar name are expected to have the same genotype due to vegetative propagation. However, this was not always the case. P. $x$ festiva cultivars 'Rosea Plena' and 'Rubra Plena' seemed not to be uniform and they did not even cluster into their own groups. However, differences between samples were small because the number of polymorphic SSRs in the 'Rosea Plenas' and 'Rubra Plenas' was not large, 3 and 8, respectively. In addition, there was uncertainty in the interpretation of some SSRs. Therefore, more markers would be needed to confirm the genetic result. On the other hand, this might also reflect a real situation because seed propagation of peonies was rather common earlier. Further, the definition of the Swedish 'Rosea Plena' and 'Mutabilis Plena' was not definitive. The three Norwegian P. officinalis 'Mollis' samples were not identical, either, but according to the importer's diaries, both seeds and living plants have been imported and the plants have been propagated from seeds for sale in Norway, which might be a reason for the variation. $P$. officinalis 'Mollis' samples in Norway are twice as tall (about $80 \mathrm{~cm}$ ) as in midSweden. Of the four P. officinalis 'Nordic Paradox' samples, one from Norway fell into duplicate Group 2 and the other from Norway and the two from Sweden into duplicate Group 3. However, the difference was only due to one somewhat uncertain allele and therefore, these four samples can be regarded as the same genotype.

There are several studies on genetic diversity in tree peonies (Gao et al. 2013; Guo et al. 2018; He et al. 2020; Ji et al. 2012; Wang et al. 2014; Wu et al. 2014) but very few in herbaceous peony species and cultivars, and especially in European cultivars. Gilmore et al. (2013) used 21 SSRs to distinguish 93 cultivars in tree, intersectional and herbaceous 
peonies, of which the last one was further separated into three species groups.

\section{Conclusions}

Most of the peony accessions that were morphologically evaluated grouped as expected in the dendrogram. This confirms that the genetic method used is reliable and will be a good base for updating Norwegian and Swedish collections and choosing specimens for the Finnish gene resources collection and for the market. There is some genetic variation within the different species. Further morphological and phenological studies will assist in choosing which specimens should be included in the collection and which specimens would be best suited for the market.

Acknowledgements The authors wish to thank Marja-Riitta Arajärvi, Minna Kavander, Pirkko Nykänen, Hannu Ojanen, and Anneli Virta for their excellent technical assistance. Finnish citizens and nurseries are thanked for providing us with the plant material. Vesa Koivu and Ahti Valli have provided valuable information on the traditional peony species. The nursery, Pionien koti, has kindly put photos at the project's disposal. The Association of Finnish Nursery Growers is thanked for providing the network of peony growers. The Finnish National Plant Genetic Resources Programme is acknowledged for supporting the call for plants and data management. Thanks to the Norwegian UiA Natural History Museum and Botanical Garden, NTNU Ringve Botanical Garden, UiT Troms $\varnothing$ ArcticAlpine Botanical Garden and MiA - Museums in Akershus for providing plant material. Botanists Brynhild Mørkved and Martin Hajman in Troms $\varnothing$ have kindly helped with information concerning $P$. officinalis 'Mollis'. Thanks to the owners of Swedish private gardens who donated plants of their older peonies and contributed so generously to the gene bank collection.

Author contributions Pirjo Tanhuanpää Conceptualisation, Methodology, Investigation, Resources, Writing-Original Draft, Writing-Review \& Editing, and Visualisation. Sirkka Juhanoja: Conceptualisation, (Methodology), Investigation, Writing-Original Draft, and Writing-Review \& Editing. Linnea Oskarsson: Investigation, Resources, Writing-Original Draft, and Writing-Review \& Editing. Mari Marstein: Investigation, Resources, Writing-Original Draft, and Writing-Review \& Editing, Funding acquisition. Merja Hartikainen: Conceptualisation, (Methodology), Investigation, Resources, Writing-Original Draft, Writing-Review \& Editing, Project Administration, and Funding Acquisition. All authors read and approved the final manuscript.

Funding Open access funding provided by Natural Resources Institute Finland (LUKE). Maiju ja Yrjö Rikalan Puutarhasäätiö and Nikolai ja Ljudmila Borisoffin Puutarhasäätiö have financed the study. The Norwegian Agriculture Agency provided financial support for collecting the Norwegian material.

Data availability The datasets generated during the study are available from the corresponding author on reasonable request.

\section{Declarations}

Conflicts of interest The authors declare that they have no known competing financial interests or personal relationships that could have appeared to influence the work reported in this paper.

Open Access This article is licensed under a Creative Commons Attribution 4.0 International License, which permits use, sharing, adaptation, distribution and reproduction in any medium or format, as long as you give appropriate credit to the original author(s) and the source, provide a link to the Creative Commons licence, and indicate if changes were made. The images or other third party material in this article are included in the article's Creative Commons licence, unless indicated otherwise in a credit line to the material. If material is not included in the article's Creative Commons licence and your intended use is not permitted by statutory regulation or exceeds the permitted use, you will need to obtain permission directly from the copyright holder. To view a copy of this licence, visit http://creativecommons.org/licenses/by/4.0/.

\section{References}

Abuzayed M, El-Dabba N, Frary A, Doganlar S (2017) GDdom: an online tool for calculation of dominant marker gene diversity. Biochem Genet 55:155-157

Anderson G (1818) A monograph of the genus Paeonia. Trans Linn Soc London 12(1):248-283

Balvoll G, Weisæth G (1994) Horticultura. Norsk hagebok frå 1694 av Christian Gartner. Page 70. Landbruksforlaget. Oslo

Botstein D, White RL, Skolnick M, Davis RW (1980) Construction of a genetic linkage map in man using restriction fragment length polymorphisms. Am J Hum Genet 32:314-331

Cheng Y, Kim C-H, Shin D-I, Kim S-M, Koo H-M, Park Y-J (2011) Development of simple sequence repeat (SSR) markers to study diversity in the herbaceous peony (Paeonia lactiflora). J Med Plants Res 5:6744-6751

Christenhusz MJM, Byng JW (2016) The number of known plants species in the world and its annual increase. Phytotaxa 261:201-217

Dark S (1936) Meiosis in diploid and tetraploid Paeonia species. Genetics 32:353-372

De Candolle AP (1818) Regni Vegetabilis Systema Naturale 1: 386-394. Paris

Gai S, Zhang Y, Mu P, Liu C, Liu S, Dong L, Zheng G (2012) Transcriptome analysis of tree peony during chilling requirement fulfillment: assembling, annotation and markers discovering. Gene 497:256-262 
Gao Z, Wu J, Liu Z, Wang L, Ren H, Shu Q (2013) Rapid microsatellite development for tree peony and its implications. BMC Genomics 14:886

Gilmore B, Bassil N, Nyberg A, Knaus B, Smith D, Barney DL, Hummer K (2013) Microsatellite marker development in peony using next generation sequencing. J Amer Soc Hort Sci 138:64-74

Guo Q, Guo L-L, Zhang L, Zhang L-X, Ma H-L, Guo D-L, Hou X-G (2017) Construction of a genetic linkage map in tree peony (Paeonia Sect. Moutan) using simple sequence repeat (SSR) markers. Sci Hortic 219:294-301

Guo L, Guo D, Zhao W, Hou X (2018) Newly developed SSR markers reveal genetic diversity and geographical clustering in Paeonia suffruticosa based on flower colour. J Hortic Sci Biotech 93:416-424

Hao L, Ma H, Texeira da Silva JA, Yu X (2016) Pollen morphology of herbaceous peonies with different ploidy levels. J Amer Soc Hort Sci 141:275-284

Harding A (1917) The book of the peony. Lippincott, Philadelphia, PA / London, UK

He D, Zhang J, Zhang X, He S, Xie D, Liu Y, Li C, Wang Z, Liu Y (2020) Development of SSR markers in Paeonia based on De Novo transcriptomic assemblies. PLoS ONE 15(1):e0227794

Homolka A, Berenyi M, Burg K, Kopecky D, Fluch S (2010) Microsatellite markers in the tree peony, Paeonia x suffruticosa (Paeoniaceae). Amer J Bot 97:e42-e44

Hong D-Y (2010) Peonies of the world: Taxonomy and phytogeography. Royal Botanic Gardens, Richmond, Surray, UK. 302 pages

Hong D-Y, Pan K-Y (2004) A taxonomic revision of the Paeonia anomala complex (Paeoniaceae). Ann Missouri Bot Gard 91:87-98

Hou XG, Guo DL, Cheng SP, Zhang JY (2011a) Development of thirty new polymorphic microsatellite primers for Paeonia suffruticosa. Biol Plant 55:708-710

Hou XG, Guo DL, Wang J (2011b) Development and characterisation of EST-SSR markers in Paeonia suffruticosa (Paeoniaceae). Am J Bot 11:e303-e305

Hsu H, Chen Y, Shen S, Hsu S, Chen C, Chang H (1986) Oriental materia medica: A concise guide. Oriental Heeling Arts Inst, Keelung, Taiwan. 932 pages

Jakubowski R, Hollingsworth D, Nordick J, Buchte H, Schroer C (2007) Peonies 1997-2007. Amer Peony Soc, Gladston, $\mathrm{MO}$

Ji L, Wang Q, Teixeira da Silva JA, Yu XN (2012) The genetic diversity of Paeonia L. Sci Hortic 143:62-74

Ji L, Teixeira da Silva JA, Zhang J, Tang Z, Yu X (2014) Development and application of 15 novel polymorphic microsatellite markets for sect. Paeonia (Paeonia L.). Biochem Syst Ecol 54:257-266

Larsson I (2009) Millefolium, rölika och näsegräs: medeltidens svenska växtvärld i lärd tradition. Kungliga Skogs-och lantbruksakademien, Stockholm

Li L, Cheng F-Y, Zhang Q-X (2011) Microsatellite markers for the Chinese herbaceous peony Paeonia lactiflora (Paeoniacea). Am J Bot 98:e16-e18

Martinsson K, Ryman S (2007) Hortus Rudbeckianus: an enumeration of plants cultivated in the Botanical Garden of Uppsala University during the Rudbeckian period 1655-1702. Acta Universitatis Upsaliensis, Uppsala
O.T. (1890). Pioner. Svenska Trädgårdsföreningens tidskrift, No. 9. Stockholm

Peltola R, Koivu V (2007) Pionit. Kustannusosakeyhtiö Tammi, Helsinki

Perrier X, Jacquemoud-Collet JP (2006). DARwin software. http://darwin.cirad.fr/darwin

Rathke J (1823) Enumeratio plantarum horti botanici Universitatis Regiae Fredericianae Christianiensis. Gröndahl, Christiania

Roldan-Ruiz I, Dendauw J, Bockstaele EV, Depicker A, Loose MD (2000) AFLP markers reveal high polymorphic rates in ryegrass (Lolium spp.). Mol Breed 6:125-134

Ruoff E (2002) Vanhoja suomalaisia puutarhoja. Otavan kirjapaino Oy, Helsinki

Saitou N, Nei M (1987) The neighbor-joining method: a new method for reconstructing phylogenetic trees. Mol Biol Evol 4:406-425

Stern FC (1946) A study of the genus Paeonia. Royal Horticulture Society, London

Sun J, Yuan JX, Wang BS, Pan J, Zhang DM (2011) Development and characterization of 10 microsatellite loci in Paeonia lactiflora (Paeoniacea). Am J Bot 98:e242-e243

Tanhuanpää P, Suojala-Ahlfors T, Hartikainen M (2019) Genetic diversity of Finnish home garden rhubarbs (Rheum spp.) assessed by simple sequence repeat markers. Genet Resour Crop Evol 66:17-25

Wan Y, Zhang M, Hong A, Zhang Y, Liu Y (2020) Characteristics of microsatellites mined from transcriptome data and the development of novel markers in Paeonia lactiflora. Genes 11(2):214

Wang J, Xis T, Zhang J, Zhou S (2009) Isolation and characterization of fourteen microsatellites from a tree peony (Paeonia x suffruticosa). Conserv Genet 10:1029-1031

Wang X, Fan H, Li Y, Sun X, Sun X, Wang W, Zheng C (2014) Analysis of genetic relationships in tree peony of different colors using conserved DNA-derived polymorphism markers. Sci Hortic 175:68-73

Wu J, Cai C, Cheng F, Cui H, Zhou H (2014) Characterisation and development of EST-SSR markers in tree peony using transcriptome sequences. Mol Breeding 34:1853-1866

Yu HP, Cheng FY, Zhong Y, Cai CF, Wu J, Cui HL (2013) Development of simple sequence repeat (SSR) markers from Paeonia ostii to study the genetic relationships among tree peonies (Paeoniaceae). Sci Hortic 164:58-64

Zhang JM, Liu J, Sun HL, Yu J, Wang JX, Zhou SL (2011) Nuclear and chloroplast SSR markers in Paeonia delavayi (Paeoniaceae) and cross-species amplification in $P$. ludlowii. Am J Bot 98:e346-348

Zhang J, Shu Q, Lui Z, Ren H, Wang L, De Keyser E (2012) Two EST-derived marker systems for cultivar identification in tree peony. Plant Cell Rep 31:299-310

Zhao DQ, Hao ZJ, Tao J (2012) Effects of shade on plant growth and flower quality in herbaceous peony (Paeonia lactiflora Pall.). Plant Physiol Biochem 61:187-196

Publisher's Note Springer Nature remains neutral with regard to jurisdictional claims in published maps and institutional affiliations. 